\title{
Alkaline Protease Production Using Proteinaceous Tannery Solid Waste
}

\author{
Javed Ahmad* and Tauseef A Ansari
}

Department of Biochemical Engineering and Food Technology, Harcourt Butler Technological Institute, Nawabganj, Kanpur 208002, India

\begin{abstract}
Leather industry has commonly been associated with high pollution due to the bad smell, organic wastes and high water consumption caused during traditional manufacturing processes. Different forms of waste in quality and quantity, which emerge during the transformation of hides and skins into leathers in thousands of leather factories, from primitive to modern all around the world, have negative impacts on the environment. In leather factories solid waste containing protein that constitute more than $60 \%$ of raw hide weight are disposed to the environment without turning them into good use at industrial level. A biological approach such as alkaline protease production by different microorganism is prominent way to utilization of tannery proteinaceous solid waste.

In this research work four different species Bacillus licheniformis, Bacillus coagulans, Bacillus polymxa and Bacillus amyloliquefaciens were isolated from soil sample and identified by biochemical tests. These species efficiently produce alkaline using animal fleshing (ANFL) which is an untanned tannery solid waste as prominent source of protein .The efficiency of protease production was measured on different temperature, pressure and incubation time. Bacillus licheniformis gave highest protease production. Due to efficient production of alkaline protease by same bacillus species, it can be use at industrial level.
\end{abstract}

Keywords: Leather industries; Environment; Solid waste; ANFL; Biological process; Bacillus species; Alkaline proteases

\section{Introduction}

The leather industry generally uses hides and skins as raw materials, which are the by-products of meat and meat products industry [1]. So in this reverence the leather industry is an environmentally friendly industry because it processes waste products from meat production industries [2]. However, the leather industry has frequently been allied with high pollution due to the bad smell, organic wastes and high water consumption caused during traditional manufacturing and processing [3]. Diverse types of waste in quality and quantity, which come out during the process of hides and skins into leathers in many leather factories, impacts negatively on the environment to all around the world [1].

Solid waste generated in leather industry is contribute mainly through processes like skin trimming keratin waste, flesh waste chrome shaving waste and buffing waste. Its main component is protein. If these proteins and other chemical which are present in the chemical treated protein are not utilized properly it will pose hazardous pollution problem to the environment [4]. The microorganisms represent an exceptional source of protease owing to their extensive biochemical diversity and susceptibility to genetic manipulation. Among the various proteases, bacterial proteases are the generally most noteworthy than others such as animal and fungal proteases [5]. The proteolytic enzymes have many physiological functions, ranging from the generalized protein digestion to the more specific regulated processes [6,7]. Alkaline proteases, an important group of industrial enzymes (Figure 1), are produced by a wide range of microorganisms, including fungi and bacteria. Bacillus $s p p$. have been reported to produce alkaline protease from various substrates, viz. green-gram husk [8], mustered-oil cake, wheat bran, rice bran, Impetrate cylindrical grass, banana leaves, potato peels and used tea leaves [9], wheat bran and lentil husk [10]. However, few reports are available on alkaline proteolytic enzymes from Bacillus cereus [11].

ANFL is one of the major solid wastes that are generated during pretanning process of leather industry operation [12] (Figure 1). It contains the highest protein content (50 to $60 \%)$ [13,14]. ANFL discharged from the tannery industries are processed by different types of chemical or thermal operation. This is an energy intensive and time consuming process [15].

In our study, alkaline proteases were produced from various microorganisms by using untanned (ANFL) as substrate. Microbial isolates species are Bacillus licheniformis, Bacillus coagulans, Bacillus polymxa and Bacillus amyloliquefaciens. The alkaline protease generally used as biocatalyst for industrial and laboratory purposes [16]

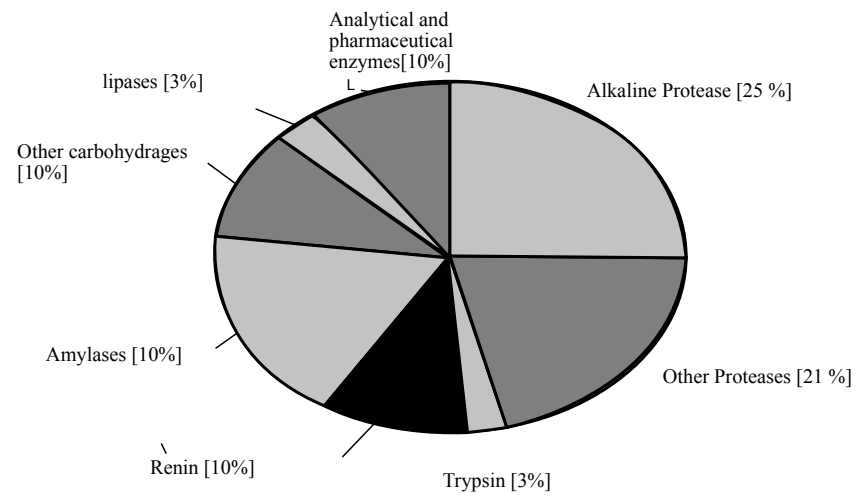

Figure 1: The contribution of different enzymes to the total sale of enzymes is indicated. The shaded portion indicates the total sale of proteases [12].

*Corresponding author: Javed Ahmad, Department of Biochemical Engineering and Food Technology, Harcourt Butler Technological Institute, Nawabganj, Kanpur 208002, India, Tel: +91-09807121672; E-mail: javedkkhaan@gmail.com

Received January 03, 2013; Accepted January 16, 2013; Published January 18 2013

Citation: Ahmad J, Ansari TA (2013) Alkaline Protease Production Using Proteinaceous Tannery Solid Waste. J Pet Environ Biotechnol 4: 136. doi:10.4172/2157-7463.1000136

Copyright: ( 2013 Ahmad J, et al. This is an open-access article distributed unde the terms of the Creative Commons Attribution License, which permits unrestricted use, distribution, and reproduction in any medium, provided the original author and source are credited. 
Proteases constitute at least $65 \%$ of the total industrial enzyme market [17]. They are used for various industrial applications, such as laundry detergents, protein recovery, leather preparation, solubilisation and organic synthesis [18]. Alkaline proteases have many physiological functions, ranging from generalized protein digestion to more specific regulated procedures [7]. Bacillus licheniformis and Bacillus coagulans can be used profitably for large scale production of alkaline protease to meet the present day demand of the industrial sector [19].

Chemical composition of tannery solid waste used in experiment

$\begin{array}{lcc}\text { Chemicals } & & \text { \% in dry } \\ \text { Protein } & - & 79 \\ \text { Fat } & - & 7.57 \\ \mathrm{P} & - & 1.476 \\ \mathrm{~K} & - & 0.47 \\ \mathrm{Ca} & - & 0.59 \\ \mathrm{Iron} & - & 2.24 \\ \mathrm{Mg} & - & 1.84 \\ \mathrm{Zn} & - & 0.116 \\ \mathrm{Cu} & - & 0.002\end{array}$

\section{Material and Method}

\section{Sample collection}

Soil samples collection area was campus area of Chander Shekhar Azad Agriculture University, Kanpur (Near H.B.T.I., Kanpur Main Campus) Nawabganj, Kanpur District, and Uttar Pradesh in the month of July. The samples were collected at a depth of $8 \mathrm{~cm}$ to $10 \mathrm{~cm}$ in soil. The collected soil samples were brought to the laboratory in sterilized caped flask, air dried \& air tied and stored at room temperature. $1( \pm 0.04)$ gram of soil sample was taken in conical flask $(250 \mathrm{ml})$ containing 100 $\mathrm{ml}$ sterile distilled water (DW).

The content was mixed well for homogenous mixture. This suspension was serially diluted up to $10^{-5}$ with sterile distilled water. The samples were transferred aseptically to Petri dishes containing sterile nutrient agar medium by pour plating technique. After inoculation, plates were incubated at $35-37^{\circ} \mathrm{C}$, for 2 to 4 days. After that Bacterial colonies appeared. Then cultures were identified based on characteristics and they were identified by the help Gram staining methods and by biochemical tests as suggested by Bergey's manual [20] as well as Cappuccino and Sherman [21]. Colonies were examined by microscopic observations. The analysis of physiological and biochemical characteristics (Table 1) of colonies were done by using methods, as suggested by Josey et al. [22] and Watanabe and Hayano [23] respectively. Here the biochemical tests have shown only for the Bacillus Species, although testing has been done on most of the colonies.

\section{Inoculums preparation}

B. licheniformis, B. coagulans, B. Polymxa and B. amyloliquefaciens were found predominantly in the soil sample. The pure culture of test organisms was maintained in nutrient agar slants for further studies for a period of $24 \mathrm{~h}$.

\section{Substrate preparation}

The sufficient amount of ANFL, of Beef skins were collected from a commercial tannery, Jajmau Industrial Area, Kanpur, India. It was treated with ammonium chloride $(1.25 \% \mathrm{w} / \mathrm{v})$ for $3-4 \mathrm{~h}$ to remove the adsorbed calcium salts on the collagen fibres. The delimed ANFL fleshing was suspended in water for 1 to $2 \mathrm{~h}$ at neutral $\mathrm{pH}$ [23]. Very small pieces of ANFL were obtained by manual scissoring. The $24 \mathrm{~h}$ grown culture of B. licheniformis, B. coagulans, B. Polymxa and B. amyloliquefaciens were inoculated in sterilized minimal medium and poured into the ANFL containing flask initial moisture content maintained at $60-65 \%$.

\section{Optimization of enzyme activity}

To optimize the alkaline protease production at various levels, as the effect of $\mathrm{pH}$, temperature and harvest time on alkaline production protease production by B.licheniformis, B. coagulans, B. polymxa and $B$. amyloliquefaciens were monitored in the minimal salt medium containing ANFL. Protease activity was determined for $98 \mathrm{~h}$ with an interval of $14 \mathrm{~h}$. Incubation periods were set as 14, 28, 42, 56, 84 and $98 \mathrm{~h}$ for a wide range study. Protease production efficiency obtained at wide range of temperatures $\left(30,40,50,60,70\right.$ and $\left.80^{\circ} \mathrm{C}\right)$ and $\mathrm{pH}(5.5$, $6.5,7.5,8.5,9.5,10.5$, and 11.5). Estimation of enzyme did as prescribed by Neheta et al. [24].

\section{Results}

\section{Effect of $\mathrm{pH}$ levels on alkaline protease production}

The effect of $\mathrm{pH}$ on enzyme production is shown in following Table 2 and Figure 2. All the microorganism were able to produce high levels of enzyme at $\mathrm{pH}$ 9.5.The Bacillus licheniformis was able to produce highest level of enzyme $(0.170 \pm 0.099 \mathrm{mg} / \mathrm{l})$ at $\mathrm{pH} 9.5$ with respect to others. All the steps done in triplicates.

\section{Effect of temperatures on alkaline protease production}

The effect of temperature on enzyme production is shown in fallowing Table 3 and Figure 3. All the microorganism were able to produce high levels of enzyme at $30^{\circ} \mathrm{C}$, the optimal temperature for alkaline protease production. The Bacillus licheniformis was able to produce highest level of enzyme $(0.214 \pm 0.099 \mathrm{mg} / \mathrm{l})$ at $30^{\circ} \mathrm{C}$ with respect to others. All the steps done in triplicates.

\section{Effect of incubation periods on alkaline protease production}

The effect of incubation periods on enzyme production is shown

\begin{tabular}{|c|c|c|c|c|c|}
\hline Sr.No. & $\begin{array}{c}\text { Biochemical } \\
\text { Test }\end{array}$ & $\begin{array}{c}\text { B. } \\
\text { licheniformis }\end{array}$ & $\begin{array}{c}\text { B. } \\
\text { coagulans }\end{array}$ & B. polymxa & $\begin{array}{c}\text { B. } \\
\text { amyloliquefaciens }\end{array}$ \\
\hline 1 & $\begin{array}{c}\text { Gram's } \\
\text { Staining }\end{array}$ & + & + & + & + \\
\hline 2 & $\begin{array}{c}\text { Nitrate } \\
\text { reduction } \\
\text { test }\end{array}$ & - & - & - & - \\
\hline 3 & $\begin{array}{c}\text { Catalase } \\
\text { test }\end{array}$ & - & - & - & - \\
\hline 4 & $\begin{array}{c}\text { Starch } \\
\text { hydrolysis } \\
\text { test }\end{array}$ & + & + & + & + \\
\hline 5 & $\begin{array}{c}\text { Mac Conkey } \\
\text { agar test }\end{array}$ & + & + & + & + \\
\hline 6 & $\begin{array}{c}\text { Citrate } \\
\text { utilization } \\
\text { test }\end{array}$ & + & + & + & + \\
\hline 7 & $\begin{array}{c}\text { Nitrate } \\
\text { Reduction }\end{array}$ & - & - & - & - \\
\hline
\end{tabular}

Table 1: Biochemical Characteristic of isolated bacteria. (+positive result -Negative result). 
Citation: Ahmad J, Ansari TA (2013) Alkaline Protease Production Using Proteinaceous Tannery Solid Waste. J Pet Environ Biotechnol 4: 136. doi:10.4172/2157-7463.1000136

in fallowing Table 4 and Figure 4 . All the microorganism were able to produce high levels of enzyme at incubation time period $98 \mathrm{~h}$, the optimal time period for alkaline protease production. The Bacillus licheniformis was able to produce highest level of enzyme $(0.186 \mathrm{mg} / \mathrm{l})$ at $98 \mathrm{~h}$ with respect to others. All the steps done in triplicates.

\section{Conclusion}

The leather industries are widely known for its effluent problems and environment pollution. The biological approach discussed is one of the best ways to solve this problem as well as utilization. Our results

\begin{tabular}{|c|c|c|c|c|c|}
\hline S.No & $\begin{array}{c}\text { The } \\
\text { level of } \\
\text { pH }\end{array}$ & $\begin{array}{c}\text { B.licheniformis } \\
\text { (mg/l) }\end{array}$ & $\begin{array}{c}\text { B. Polymxa } \\
\text { (mg/l) }\end{array}$ & $\begin{array}{c}\text { B. } \\
\text { amyloliquefaciens } \\
\text { (mg/l) }\end{array}$ & $\begin{array}{c}\text { B. coagulans } \\
\text { (mg/l) }\end{array}$ \\
\hline $\mathbf{1 .}$ & $\mathbf{6 . 5}$ & $0.138 \pm 0.099$ & $0.132 \pm 0.098$ & $0.141 \pm 0.099$ & $0.135 \pm 0.099$ \\
\hline $\mathbf{2 .}$ & $\mathbf{7 . 5}$ & $0.146 \pm 0.099$ & $0.137 \pm 0.098$ & $0.148 \pm 0.099$ & $0.141 \pm 0.099$ \\
\hline $\mathbf{3 .}$ & $\mathbf{8 . 5}$ & $0.178 \pm 0.099$ & $0.145 \pm 0.099$ & $0.159 \pm 0.099$ & $0.151 \pm 0.098$ \\
\hline $\mathbf{4 .}$ & $\mathbf{9 . 5}$ & $0.191 \pm 0.098$ & $0.151 \pm 0.099$ & $0.171 \pm 0.099$ & $0.161 \pm 0.099$ \\
\hline $\mathbf{5 .}$ & $\mathbf{1 0 . 5}$ & $0.170 \pm 0.099$ & $0.145 \pm 0.098$ & $0.147 \pm 0.098$ & $0.143 \pm 0.098$ \\
\hline $\mathbf{6 .}$ & $\mathbf{1 1 . 5}$ & $0.168 \pm 0.099$ & $0.142 \pm 0.099$ & $0.145 \pm 0.099$ & $0.141 \pm 0.099$ \\
\hline
\end{tabular}

Table 2: Effect of $\mathrm{pH}$ levels on alkaline protease production by $B$. licheniformis, $B$. polymxa, $B$. amyloliquefaciens and $B$. coagulans. (All the steps done in triplicates).

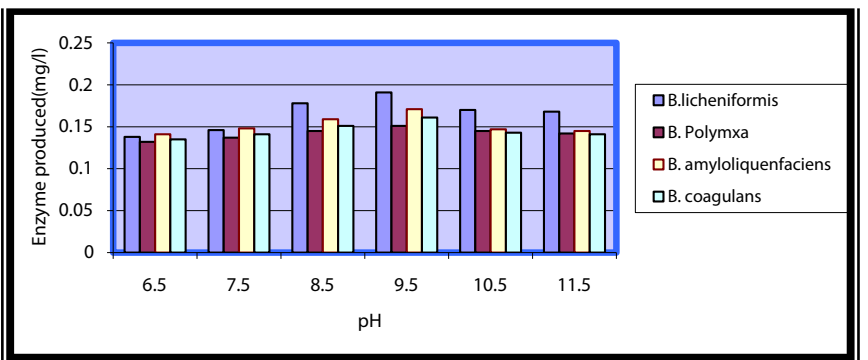

Figure 2: Effect of $\mathrm{pH}$ levels on alkaline protease production by $B$ licheniformis, B. Polymxa, B. amyloliquefaciens and B. coagulans. (All the steps done in triplicates)

\begin{tabular}{|c|c|c|c|c|c|}
\hline S.No & $\begin{array}{c}\text { Tempera } \\
\text { ture }\left({ }^{\circ} \mathbf{c}\right)\end{array}$ & $\begin{array}{c}\text { B. } \\
\text { licheniformis } \\
\text { (mg/l) }\end{array}$ & $\begin{array}{c}\text { B. Polymxa } \\
\text { (mg/l) }\end{array}$ & $\begin{array}{c}\text { B. amylolique } \\
\text { faciens }(\mathbf{m g} / \mathbf{l})\end{array}$ & $\begin{array}{c}\text { B. coagulans } \\
\text { (mg/l) }\end{array}$ \\
\hline $\mathbf{1 .}$ & $\mathbf{3 0}$ & $0.214 \pm 0.099$ & $0.198 \pm 0.099$ & $0.159 \pm 0.099$ & $0.172 \pm 0.099$ \\
\hline $\mathbf{2 .}$ & $\mathbf{4 0}$ & $0.199 \pm 0.099$ & $0.178 \pm 0.098$ & $0.156 \pm 0.099$ & $0.164 \pm 0.099$ \\
\hline $\mathbf{3 .}$ & $\mathbf{5 0}$ & $0.190 \pm 0.099$ & $0.175 \pm 0.098$ & $0.150 \pm 0.099$ & $0.160 \pm 0.098$ \\
\hline $\mathbf{4 .}$ & $\mathbf{6 0}$ & $0.185 \pm 0.099$ & $0.170 \pm 0.098$ & $0.145 \pm 0.099$ & $0.156 \pm 0.098$ \\
\hline $\mathbf{5 .}$ & $\mathbf{7 0}$ & $0.175 \pm 0.099$ & $0.165 \pm 0.098$ & $0.140 \pm 0.099$ & $0.149 \pm 0.098$ \\
\hline $\mathbf{6 .}$ & $\mathbf{8 0}$ & $0.164 \pm 0.099$ & $0.156 \pm 0.098$ & $0.131 \pm 0.099$ & $0.138 \pm 0.098$ \\
\hline
\end{tabular}

Table 3: Effect of temperature levels on alkaline protease Production by $B$ licheniformis, B. Polymxa, B. amyloliquefaciens and B. coagulans. (All the steps done in triplicates).

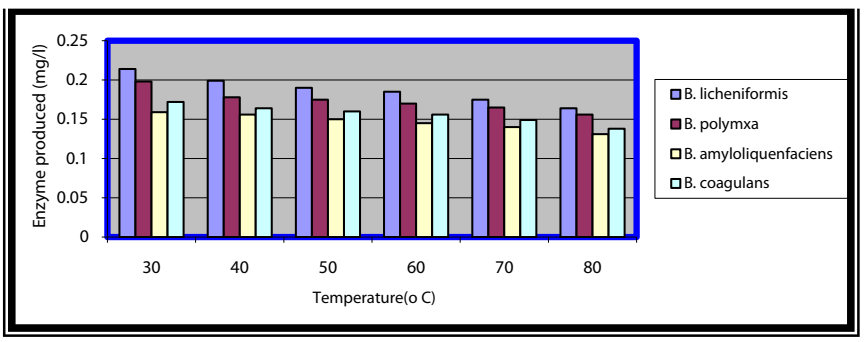

Figure 3: Effect of temperature levels on alkaline protease Production by $B$. licheniformis, B. Polymxa, B. amyloliquefaciens and B. coagulans. (All the steps done in triplicates)

\begin{tabular}{|c|c|c|c|c|c|}
\hline S.No & $\begin{array}{c}\text { Incubation } \\
\text { time (h) }\end{array}$ & $\begin{array}{c}\text { B.licheniformis } \\
\text { (mg/l) }\end{array}$ & $\begin{array}{c}\text { B. polymxa } \\
\text { (mg/l) }\end{array}$ & $\begin{array}{c}\text { B. amylolique } \\
\text { faciens }(\mathbf{m g} / \mathbf{l})\end{array}$ & $\begin{array}{c}\text { B.coagulans } \\
\text { (mg/l) }\end{array}$ \\
\hline $\mathbf{1}$ & $\mathbf{1 4}$ & $0.146 \pm 0.103$ & $0.136 \pm 0.103$ & $0.142 \pm 0.103$ & $0.132 \pm 0.102$ \\
\hline $\mathbf{2}$ & $\mathbf{2 8}$ & $0.154 \pm 0.102$ & $0.146 \pm 0.102$ & $0.149 \pm 0.102$ & $0.138 \pm 0.103$ \\
\hline $\mathbf{3}$ & $\mathbf{4 2}$ & $0.161 \pm 0.103$ & $0.151 \pm 0.102$ & $0.157 \pm 0.103$ & $0.147 \pm 0.102$ \\
\hline $\mathbf{4}$ & $\mathbf{5 6}$ & $0.164 \pm 0.102$ & $0.156 \pm 0.103$ & $0.165 \pm 0.102$ & $0.154 \pm 0.103$ \\
\hline $\mathbf{5}$ & $\mathbf{8 4}$ & $0.178 \pm 0.102$ & $0.169 \pm 0.102$ & $0.176 \pm 0.103$ & $0.168 \pm 0.102$ \\
\hline $\mathbf{6}$ & $\mathbf{9 8}$ & $0.186 \pm 0.102$ & $0.179 \pm 0.102$ & $0.185 \pm 0.102$ & $0.172 \pm 0.103$ \\
\hline
\end{tabular}

Table 4: Effect of incubation periods on alkaline protease production by $B$. licheniformis, B. Polymxa, B. amyloliquefaciens and B. coagulans. (All the steps done in triplicates).

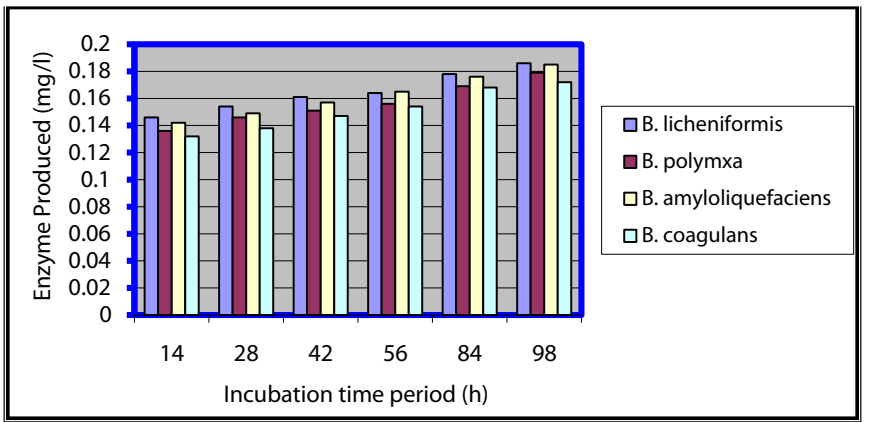

Figure 4: Effect of incubation periods on alkaline protease production by $B$. licheniformis, B. Polymxa, B. amyloliquefaciens and B. coagulans. (All the steps done in triplicates).

indicated that optimum condition for alkaline protease productivity on the basis of $\mathrm{pH}$, temperature and pressure. Characterization as well as optimization for each feature of growth and production yield is essential requirements. Bacillus licheniformis gave best result for maximum efficiency. It can be use on industrial level. Further research is required on full purification of alkaline protease for its complete utilization and meeting the needs of the industry.

\section{Acknowledgement}

Authors thank Associate Professor S.J. Nagar and (H.B.T.I. KANPUR) for their support and encouragement.

\section{Reference}

1. Ozgunay H, Colak S, Mutlu MM, Akyuz F (2007) Characterization of Leather Industry Wastes. Polish J of Environ stud 16: 867-873.

2. Lang MF, Kolozmik K, Sukop S, Mla DM (1999) Products of enzymatic decomposition of chromium tanned leather waste. JSLTC 83: 187.

3. Taylor MM, Cabeza LF, Dimaio GL, Brown EM, Marmer WN, et al. (1998) Processing of leather waste: pilot scale studies on chrome shavings. 1. isolation and characterization of protein products and separation of chrome cake. JAL CA 93: 61-82.

4. Kanagaraj J, Velappan KC, Chanra BNK, Sadulla S (2006) Solid waste generation in leather industry and its utilization for cleaner environment- $A$ Review. Journal of Scientific and Industrial Research 65: 541-548.

5. Ward OP (1985) Proteolytic enzymes. Comprehensive Biotechnology 3: 789818.

6. Kalisz HM (1988) Microbial proteinases. Adv Biochem Eng Biotechnol 36: $1-65$.

7. Kaminishi H, Hamatake H, Cho T, Tamaki T, Suenaga N, et al. (1994) Activation of blood clotting factors by microbial proteinases. FEMS Microbio Lett 121: 327-332.

8. Prakasham RS, Rao CHS, Sarma PN (2006) Green gram husk, an inexpensive substrate for alkaline protease production by Bacillus $s p$. in solid state fermentation. Bioresour Technol 97: 1449-1454.

9. Mukherjee AK, Adhikari H, Rai SK (2008) Production of alkaline protease by 
Citation: Ahmad J, Ansari TA (2013) Alkaline Protease Production Using Proteinaceous Tannery Solid Waste. J Pet Environ Biotechnol 4: 136. doi:10.4172/2157-7463.1000136

Page 4 of 4

a thermophilic Bacillus subtilis under solid-state fermentation (SSF) condition using Imperata cylindrical grass and potato peel as low-cost medium: Characterization and application of enzyme in detergent formulation. Biochem Eng J 39: 353-361.

10. Uyar F, Baysal Z (2004) Production and optimization of process parameters for alkaline protease production by a newly isolated Bacillus $s p$. under solid state fermentation. Process Biochem 39: 1893-1898.

11. Ghorbel B, Sellami-Kamoun A, Nasri M (2003) Stability studies of protease from Bacillus cereus BG1. Enzyme Microb Technol 32: 513-518.

12. Rao MB, Tanksale AM, Mohini SG, Deshpande VV (1998) Molecular and biotechnological aspects of microbial proteases. Microbiol Mol Biol Rev 62 : 597-635.

13. Ravindran B, Dinesh SL, John Kennedy L, Sekaran G (2008) Vermicomposting of solid waste generated from leather industries using epigeic earthworm Eisenia foetida. Appl Biochem Biotechnol 151: 480-488.

14. Ganesh Kumar A, Swarnalatha S, Sairam B, Sekaran G (2008) Production of alkaline protease by Pseudomonas aeruginosa using proteinaceous solid waste generated from leather manufacturing industries. Bioresour Technol 99: 1939-1944.

15. Bajza Z, Markovic I (1999) Influence of enzyme concentration on leather waste hydrolysis kinetics. J Soc Leath Tech Ch 83: 172-176.
16. Bajza Z, Vrcek IV (2001). Water Quality Analysis of Mixtures Obtained from Tannery Waste Effluents. Ecotox Environ Safe 50: 15-18.

17. Rao NM, Sastry TP, Sivaparvathy M, Srinivasan TS (1994) Evaluation of tannery by product meal for broiler. Ind J Poultry Sci 29: 37-41.

18. Anwar A, Saleemuddin M (1998) Alkaline proteases: A review. Bioresou Technolology 64: 175-183.

19. Asokan S, Jayanthi C (2010) Alkaline protease production by Bacillus licheniformis and Bacillus coagulans. Journal of cell and tissue research 10 2119-2123.

20. Bergey D (1957) Bergey's Manual of Determinative Bacteriology. American Society for Microbiology: VII Edition. Williams \& Willkins Co Publishers, Baltimore, USA.

21. Cappuccino JG, Sherman N (1999) Foloia Microbial. 6: 231-245.

22. Josey P, Beyho JL, Johnson AWB, Beringer JE (1979) J Appl Bacteriol 46: 343-350.

23. Witanabe K, Hayano L (1994) J Biol Fert Soil 18: 341-346.

24. Nehete PN, Shaj VD, Kothari RM (1986) Enzyme Microbial Technol 8: 370-374 